\title{
Exploring the Relationship between Learners Gender Differences and Communication Apprehension Considering the Class Participation in Iranian EFL Context
}

\author{
Ali Faridizad*, Shahla Simin \\ English Department, Najaf Abad Branch, Islamic Azad University, Najaf Abad, Isfahan, Iran \\ *E-mail address: afaridizad26@gmail.com, shahlasimin@yahoo.com
}

\begin{abstract}
The ability to communicate effectively is the optimum goal of learning English. Class participation plays a pivotal role in improving oral communication. Some obstacles prevent students from reaching class participation which may halt student' potent communication. Oral communication apprehension has been found to be the most important factor affecting the class participation. With all the differences separating males and females, it is no surprise that communication apprehension would be affected by gender differences. The goal of this study is to investigate the relationship between learners' gender differences and oral communication apprehension with respect to class participation. To achieve this goal, 140 undergraduate students including 70 males and 70 females majoring in English literature, translation and teaching from Sheik-Bahai University were selected. This sample was chosen by means of simple random sampling procedure. A questionnaire was utilized as the instrument to examine the relationships between learners' gender differences and oral communication apprehension. The data accumulated by means of the questionnaire were analyzed to ascertain the answers to the research question. In general, the findings showed that female students tend to be more apprehensive than men regarding the class participation.
\end{abstract}

Keywords: Oral communication apprehension; learners' gender differences; class participation

\section{INTRODUCTION}

The English language is certainly the most dominant world language. Knowing English opens up unimaginable opportunities in life. Being able to communicate is the ultimate purpose of learning language. In EFL contexts in which learners are not actually exposed to authentic language, one major way to practice communication is through class participation. To put it another way, classroom is the only place learners can have opportunities to foster and improve their communicative competence. Classroom participation can be activated significantly by the instructors through activities such as posing questions, permitting students to ask questions or offer comments, and structuring small group activities (Williams, 1971). However, there are some obstacles to achieving classroom participation which may hinder students' effective communication. In particular, Oral Communication Apprehension (OCA) has been found to be an important factor influencing classroom participation. 
The concept of OCA is defined by McCroskey (1977) as "an individual level of fear or anxiety associated with either real or imagined communication with another person or persons" (p.78). Even with high communication skill, apprehensive learners talk less and are less satisfied with their communication with others (McCroskey \& Beatty, 2000). Therefore, to improve class participation of learners, OCA has been the subject of numerous studies (Brown \& Puris, 1958; McCroskey \& Richmond, 1975; Neer \& Kirecher, 1989).

The current study attempts to constitute the existence or non-existence of the relationship between learners' gender differences and oral communication apprehension with respect to class participation.

\section{LITERATURE REVIEW}

Communication apprehension is one perspective dealing with general concern about problems with communication avoidance and anxiety (McCroskey, 1984). Neer (1987) defined communication apprehension, especially classroom apprehension, as "avoidance of participation prompter by evaluation apprehension or expectation of negative outcomes associated with participation"(p.157).

There is strong evidence for the importance of participating in class (Lyons, 1989; Petress, 2006; Weaver \& Qi, 2005). Junn (1994) believed that participation in the class could enhance students' motivation. Weaver and Qi (2005) found that those who participate in classroom discussions regularly learn better. Another benefit stated by Kuh and Umbach (2004) was self-reported gains in characters for those who participate in the class. Moreover, a study conducted by Crone (1997) revealed that classroom participation has effects on enhancing learners' critical thinking. Students who participate in discussions also show improvement in group interactions (Armstrong \& Boud, 1983), and functioning in a democratic society (Girgin \& Stevens, 2005).

Fassinger (1995) noted that both students and professors can see the benefits of student participation, and Fritschner (2000) found that students thought participation was "essential" to their own learning. Handelsman et al. (2005) observed a positive relationship between frequency of participation and learners' grades, with high frequency of classroom participation associated with higher grades achieved by students.

There are various reasons, both speculative and empirically supported, that students fail to participate in class. One major reason is class size. Gleason (1986) found that large classes tend to hamper communication among learners. Myers et al, (2009) discovered that students were more willing to participate in small class discussions in comparison to the large ones. Weaver and Qi (2005) found that in small classes students are less likely to hide. Howard, Short, and Clarck (1996) found class size to be more predictive of participation than sex. Karp and Yoels (1976) found that while the number of students who participate in any given classroom is often the same, courses which have more than 40 students have fewer overall interactions per class period.

Another reason students may not participate in class is because of their own personal fears of feeling inadequate in front of others, regardless of the logistics of the classroom setting. Armstrong and Boud (1983), Fritschner (2000), Howard and Henney (1998), Hyde and Ruth (2002), Karp and Yoels (1976), and Weaver and Qi (2005) all noted that students may feel intimidated or inadequate in front of their classmates and professors, and thus choose not to participate. Students even reported confidence as the most motivating factor for their participation in several studies (Weaver \& Qi, 2005). 
This concern about being nervous and lacking confidence follows closely with McCroskey's (1984) research on communication apprehension, which can be trait- or situation-specific. Individuals who may not be particularly high in communication apprehension as a trait are still frequently anxious about communicating in certain situations (e.g., public speaking, meetings). Stemming from situational communication apprehension is classroom apprehension, the "avoidance of participation prompted by evaluation apprehension or expectation of negative outcomes associated with participation" (Neer, 1987, p. 157).

Daly and Miller (1995) observed that females had slightly higher rates of CA than males. They studied 122 teacher-students by administering the PRCA-24. The apprehension levels of women were greater than the apprehension levels of men. Likewise, Elias (1999) investigated the level of oral communication apprehension between male and female accounting students. He found that female accounting students were significantly more apprehensive than their male counterparts.

As in the previous study, Johnson and Faunce (1973), also, indicated that females expressed greater anxiety about speaking in front of the class. As for Aly and Islam (2005) gender, job status, grade point average and years of experience have an effect on CA. In line with most studies, Aly and Islam (2005) found that females experience a higher level of CA than men. Moreover, Hassal, Joyce, Ottewill, Aequero, and Donoso (2002) studied communication apprehension in the United Kingdom among Spanish business and accounting students and noted significant differences in the levels of CA with females having higher levels.

Recently, some studies were conducted to consider the relationship between OCA and gender in Iranian context. For instance, Rashidi, Yamini, and Shafiei (2010) conducted a study in an Iranian context to propose a causal model of factors that would predict OCA. Along with self-esteem, introversion/extroversion, and proficiency level, they also studied gender effect. Data collection was done by three questionnaires. Results of the study revealed that females experienced a higher level of OCA.

Although the results of forgoing studies were all indicators of higher levels of OCA in females, they were not devoid of limitations. One major limitation addressed by all of them was the small sample size. Thus, the generalizability of the findings is limited.

In contrast to the aforementioned studies, some studies found male students as more apprehensive than females. For example, $\mathrm{Na}$ (2007) surveyed 115 students from a high school in Shandong Province, China to explore high school students' English learning anxiety in Chinese EFL classrooms. Gender differences were also taken into account. The results indicated that students, indeed, had comparatively high anxiety in English learning. Males had higher anxiety in English classes than females. Moreover, Borzi and Mills (2001) found the male accounting majors have a higher level of CA than female accounting majors.

Similarly, Lin and Rancer (2003) found males more apprehensive than females. They studied 130 men and 175 women to determine if gender predisposes interactions between individuals from different cultures. This study examined apprehension about intercultural communication, ethnocentrism and intercultural willingness to communicate. The study concluded that adult males reported experiencing higher CA when involved in intercultural communication, being more ethnocentric and being less willing to communicate interculturally than females.

In sum, considering the contradictory findings and the limitations of the previous studies, it seems that OCA is a controversial issue with regard to gender. Thus, conducting a study to extend the findings and offer new insights to the literature is both essential and helpful. 


\section{METHODOLOGY OF THE STUDY}

\subsection{Participants}

The accessible population for this study included undergraduate students majoring in English literature, English translation, and English language teaching in Sheikh Bahai University, Isfahan, Iran. The participants selected for the present study comprised 140 students. Participants were divided into two groups of male and female. Each group consisted of 70 students. The participants' first language was Persian. This sample was chosen from the accessible population mentioned above by means of simple random sampling procedure.

\subsection{Instruments}

The main instrument of the study is a questionnaire used to examine the relationships between learners' gender difference and oral communication apprehension. Each section was designed precisely to measure the specific variables of the study.

\subsection{Data collection}

"The survey method is one of the most important data collection methods in the social sciences, and as such it is used extensively to collect information on numerous subjects of research" (Nachmias \& Nachmias, 2007, p. 225). A survey can be through questionnaires, personal interviews, telephone surveys, or via the Internet. Therefore, a questionnaire was used for this study to examine the relationships between learners' gender differences and Communication Apprehension.

\subsection{Data analysis}

The current study employed a version of the survey instrument that included only quantitative items. Thus, the survey exclusively contained closed-ended questions. The items were grouped into scales, as well as demographic information. The scales specifically examined variables addressed in the study. The data accumulated by means of the questionnaire were analyzed to determine the answer to the research question. In so doing, the software, Statistical Packages for the Social Sciences (SPSS), was run.

\section{RESULTS}

As it was noted earlier in the study, the purpose of this study was to unearth possible relationships between Oral communication apprehension and learners' gender differences. The study was guided by a research question. The following tables and figure indicate the descriptive and inferential statistics of results. 


\subsection{Answering the research Question}

The research question of the study mentioned below will be answered. The results also would be yielded in details.

RQ: Does gender of Iranian EFL learners play any significant role in their degree of oral communication apprehension?

H: Gender of Iranian EFL learners does not play any significant role in their degree of oral communication apprehension.

Table 4.1. Provides the descriptive statistics for OCA with regard to gender.

Table 4.1. Descriptive statistics of OCA.

\begin{tabular}{|c|c|c|c|}
\hline OCA & $\mathrm{N}$ & Mean & Std. Deviation \\
\hline Male & 70 & 66.1856 & 28.04882 \\
\hline Female & 70 & 90.7805 & 23.11217 \\
\hline
\end{tabular}

As presented in table 4.1, the mean score of females $(M=90.7805)$ is higher than males $(\mathrm{M}=66.1856)$. To identify the significance of the mean difference, Independent Sample T-test was utilized. (Table 4.2)

Table 4.2. Results of Independent Sample T-test of OCA for gender.

\begin{tabular}{|c|c|c|c|c|c|c|c|c|c|}
\hline \multirow{3}{*}{ ర্ } & \multicolumn{2}{|c|}{$\begin{array}{c}\text { Levene's Test } \\
\text { for Equality of } \\
\text { Variances }\end{array}$} & \multicolumn{7}{|c|}{ t-test for Equality of Means } \\
\hline & \multirow{2}{*}{\multicolumn{2}{|c|}{$\mathrm{F}$}} & \multirow[t]{2}{*}{ Sig. } & \multirow[t]{2}{*}{$\mathrm{T}$} & \multirow[t]{2}{*}{ Df } & \multirow[t]{2}{*}{$\begin{array}{c}\text { Sig. } \\
\text { (2-tailed) }\end{array}$} & \multirow[t]{2}{*}{$\begin{array}{c}\text { Mean } \\
\text { Difference }\end{array}$} & \multirow[t]{2}{*}{$\begin{array}{l}\text { Std. Error } \\
\text { Difference }\end{array}$} & $\begin{array}{l}95 \% \text { Confidence } \\
\text { Interval of the } \\
\text { Difference }\end{array}$ \\
\hline & & & & & & & & & \begin{tabular}{l|l} 
Lower & Upper \\
\end{tabular} \\
\hline 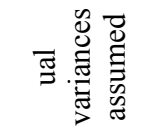 & 4.090 & 0.44 & -7.663 & 259 & .000 & -24.59492 & 3.20936 & -30.91468 & -18.27516 \\
\hline 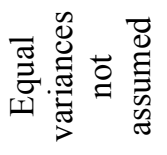 & & & -7.295 & 172.22 & .000 & -25.59492 & 3.37132 & -31.24994 & -17.93990 \\
\hline
\end{tabular}

$\mathbf{P}<.05$ 
As demonstrated by table 4.2 the t-observed $(\mathrm{F}=4.090)$ was significant at $\mathrm{P}<.05$, indicating that there is a meaningful difference between males and females' degree of OCA. According to the mean score presented in table 4.2, it shows that women tend to be more apprehensive than men. As in the previous research question, the null hypothesis is rejected.

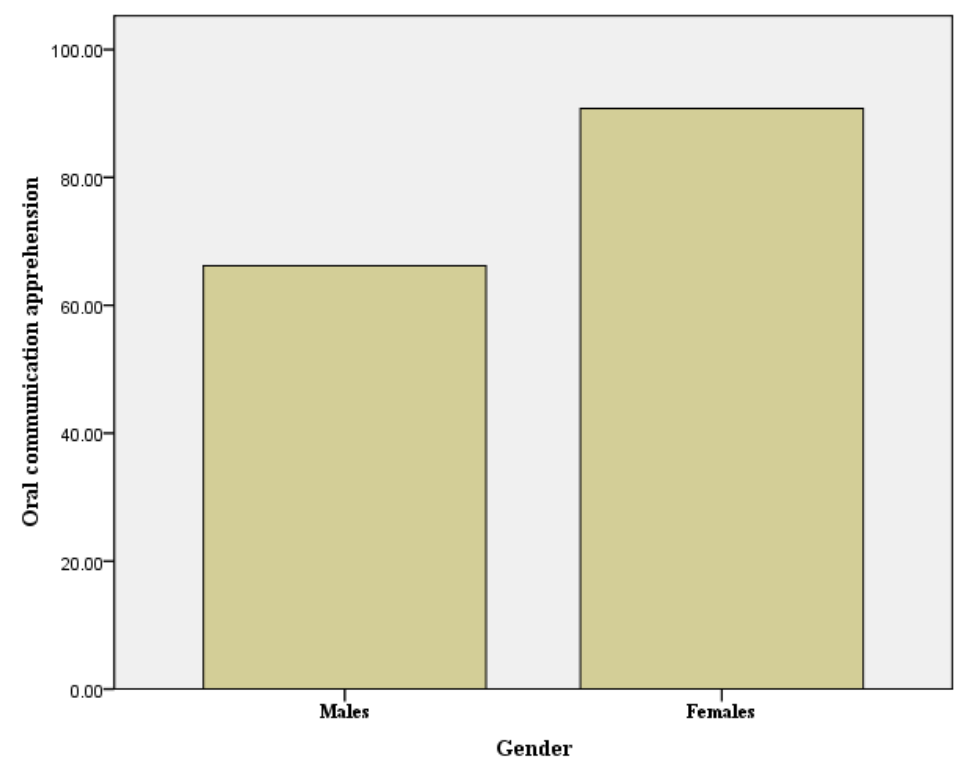

Figure 4.1. Mean score of oral communication apprehension with regard to gender.

Figure 4.1 demonstrates the mean score of OCA in males and females. This figure shows females have a higher mean score than males which means that women experience more OCA than men.

\section{DISCUSSION AND CONCLUSION}

This study was constructed to unveil the relationship between learners' gender differences and oral communication apprehension. 140 participants from Sheikh Bahai University were surveyed. Statistical analyses were done via both bivariate procedures. Upon the analyses of the data, the researcher found the significant differences between males and females with respect to oral communication apprehension.

A conclusion could be drawn from the findings. Women were found to be more apprehensive than men and, therefore, less willing and hesitant to contribute to class discussions. The upshots of the study appear to be quite promising to help educators and researchers give communication apprehension more careful considerations considering the gender differences.

\section{IMPLICATIONS}

The outcomes about the relationship between learners' gender differences and oral communication apprehension provide new insights into the factors affecting class participation and open the avenues for further research in the field. Degree of oral communication apprehension was found to be stronger among women. The findings on the roles of gender refuted the claims that males are more apprehensive than females (Na, 2007; 
Borzi \& Mills, 2001; Lin \& Rancer, 2003). The results of the current study can contribute greatly to positive educational changes by helping educators and instructors consider the gender differences regarding oral communication apprehension to employ efficient methods and techniques to optimize effective classroom participation.

\section{References}

[1] Aly, I., \& Islam, M. (2005). Factors affecting oral communication apprehension among business students: An empirical study. The journal of American academy of business, 2, 98-103.

[2] Borzi, M. G., \& Mills, T. H. (2001). Communication apprehension in upper level accounting students: An assessment of skill development. Journal of Education for Business, 76(4), 193-198.

[3] Armstrong, M., \& Boud, D. (1983). Assessing participation in discussion: An exploration of the issues. Studies in Higher Education, 8(1), 33-44.

[4] Cohen, M. (1991). "Making class participation a reality, "Political Science and Politics, Vol 24, No. 4, p.699-703.

[5] Crone , J. A. (1997) Using panel debates to increase student involvement in the introductory sociology class. Teaching Sociology, 25, 214-218.

[6] Cupach, W. R., \& Carson, C. L. (2002). Characteristics and consequences of interpersonal complaints associated with perceived face threat. Journal of Social and Personal Relationships, 19(4), 443-462.

[7] Daly, J. A.\& Miller M.D. (1975). Further studies in writing apprehension: SAT scores, success expectations, willingness to take advanced courses, and sex diiferences. Research in the Teaching of English, 9(3), 250-256.

[8] Elias, R. Z. (1999). An examination of nontraditional accounting students' communication apprehension and ambiguity tolerance. Journal of education for business, $75(1), 38-41$.

[9] Fassinger, P. A. (1995). Understanding classroom interaction. The Journal of Higher Education, 66, 82-96.

[10]Fritschner, L. M. (2000). Inside the undergraduate college classroom: Faculty and students differ on the meaning of student participation. The Journal of Higher Education, $71,342-362$

[11] Girgin, K. Z., \& Stevens, D. D.(2005). Bridging in-class participation with innovative instruction: Use and implications in a Turkish university classroom. Innovations in Education and Teaching International, 42, 93-106.

[12]Gleason, M. (1986). Better communication in large classes. College Teaching, 34, 20-24.

[13]Handelsman, M. M., Briggs, W. L., Sullivan, N., \& Towler, A. (2005). A measure of college student course engagement. The Journal of Educational Research, 98, 184-191. (ES) 
[14]Hassal, T., Joice, J., Ottewill, R., Aequero, J., \& Donso, J. (2002). Communication apprehension in UK and spanish business and accounting students. Education \& Training, 42, 93-100.

[15] Howard, J. R., \& Henney, A. L. (1998). Student participation and instructor gender in the mixed-age college classroom. The Journal of Higher Education, 73, 764-780.

[16]Howard, J. R., Short, L. B., \& Clark, S. M. (1996). Students' participation in the mixed age college classroom. Teaching sociology, 24, 8-24.

[17]Hyde, C. A., \& Ruth, B.J. (2002). Multicultural content and class participation: Do students self-disclose? Journal of Social Work Education, 38, 241-256.

[18]Johnson, L., \& Faunce, R. W. (1973). Minneapolis Secondary School Students' Attitudes Toward School by Achievement, Race, and Sex.

[19]Junn, E. (1994) . Pearls of wisdom: Enhancing student class participation with an innovative exercise . Journal of Instructional Psychology, 21, 385-387.

[20]Karp, D. A., \& Yoels, W. C. (1976). The college classroom : some observations on the meanings of student participation. Sociology and Social Research, 60, 421-439.

[21]Kuh, G. D., \& Umbach , P.D. (2004). College and character: Insights from the National Survey of Student Engagement. New Directions for Institutional Research , 122, 37-54.

[22]Lin, Y., \& Rancer, A. S. (2003). Ethnocentrism, intercultural communication apprehension, intercultural willingness-to-communicate, and intentions to participate in an intercultural dialogue program: Testing a proposed model.Communication Research Reports, 20(1), 62-72.

[23]Lyons, P. R. (1989). Assesing classroom participation College Teaching, 37, 36-38.

[24] McCroskey, J. C., (1984). The communication apprehension perspective. In J. A. Daly and J.C. McCroskey, Avoiding communication: Shyness, reticence, and communication apprehnsion, pp. 13-38. Beverly Hills, CA: Sage.

[25] Myers, S. A., Horan, S. M., Kennedy-lightsey, C. D., Madlock, P. E., Sidelinger, R. J., Byrnes, K., Frisby, B., \& Mansson, D. H. (2009). The relationship between college students'self -reports of class participation and perceived instructor impressions. communication Research Reports, 26, 123-133.

[26]Na, Z. (2007). A study of high school students' English learning anxiety. Iranian EFL Journal, 9(3), 22-34.

[27]Neer, M. R. (1987). The development of an instrument to measure classroom apprehension. Communication Education, 36(2), 154-166.

[28]Petress, K. (2006). An operational defenition of class participation. College Student Journal, $40,821-823$ 
[29] Rashidi, N. (2010). On the relationship between efl learners'oral communication apprehension and personality traits. Annales Universitatis Apulensis. Series Philologica, (11/4), 233-255.

[30] Wade, R. (1994). Teacher education students'views on classroom discussion: Implications for fostering critical reflection. Teaching and teacher education, 10, 231243.

[31] Weaver, R. R., \& Qi, J.(2005).classroom organization and participation: college students' perception. The Journal of Higher Education, 76, 570-601. 